\title{
Investigation into the Coagulating Properties of Acid and Enzyme Coagulated Soy Protein Precipitate
}

\author{
P. A. Ade poju", ${ }^{1, *}$ A. O. Longe ${ }^{1}$, O. B. Ode inde ${ }^{1}$, G. N. Ele mo ${ }^{2}$, O. L. Erukainure ${ }^{2}$ \\ ${ }^{\mathbf{1}}$ Food Technology Department, Lagos State Polytechnic, Ikorodu, Nigeria \\ ${ }^{2}$ Department of Food and Analy tical Services, Federal Institute of Industrial Research, Oshodi, Nigeria
}

\begin{abstract}
Precipitation is widely used in processing of biological products, such as proteins. The coagulating properties of Sodom apple juice, vinegar, lemon juice and rennet as coagulants of soy protein precipitate from soymilk at different temperature were investigated. Soymilk was produced using the hot grind method. The studied coagulants were used to precipitate soy protein from the produced milk at different temperature respectively. The coagulation time was observed to decrease with increasing temperature, with $100^{\circ} \mathrm{C}$ giv ing the best time. The $\mathrm{pH}$ of the coagulated proteins was observed to decrease with increasing temperature with the optimal $\mathrm{pH}$ observed at $70^{\circ} \mathrm{C}$ for all the coagulants. No significant difference was observed on the effect of coagulating temperatures on the yield of coagulated soy protein precipitate. Results from this study indicate that optimum coagulating activities can be achieved between $70-80^{\circ} \mathrm{C}$. However, the yields by the studied coagulants are not affected by temperature. Thus, implying that temperature modulate the coagulating activities, $\mathrm{pH}$ and not yields of the coagulants. Therefore, production at $70-80^{\circ} \mathrm{C}$ will give the best soy protein quality.
\end{abstract}

Keywords Soybeans, Soymilk, Coagulation, Soy Protein

\section{Introduction}

Protein deficiency and malnutrition is a well documented cause of ill health and death in developing countries, and plays a major role in the disease, kwashiorkor[1]. Its deficiency can also lead to several ailments including mental retardation. Food-based strategies favouring local multi-nutrient food materials have been reported to be the best suitable and sustainable approach for combating protein malnutrition[2]. A mongst such food is the soybean which contains high quality protein and readily available in most developing countries. Over the years, they have been processed and used to fortify cereal flours and other food products. The use of high-protein soy products to combat malnutrition in developing countries is now being emp loyed by several hunger-fighting organizations [3].

Soy protein is a popular food ingredient used throughout the world for its nutritional and functional properties[4]. It has gained considerable attention due to its potential role in improving risk factors for cardiovascular disease (CVD) especially after approval by FDA[5]. Their approval was based on clinical studies showing that at least $25 \mathrm{~g}$ of soy protein per day lowered total and LDL cholesterol[6]. So me clinical studies suggest that soy protein and its isoflavones

\footnotetext{
* Corresponding author:
}

lekeadepoju@hotmail.com (P.A. Adepoju)

Published online at http://journal.sapub.org/fph

Copyright (C) 2012 Scientific \& Academic Publishing. All Rights Reserved protect bone density, but this has not been firmly established. Soybean protein is regarded as complete protein since it provides all of the essential amino acids for human nutrition[7]. However, some scientific sources disagree on this as the best measure of complete protein[8]. Soybean protein is essentially identical to that of other legume pulses and is one of the least expensive sources of dietary protein[9]. These claims have led to the development of new soy foods and new technologies as well as improvement/modification of old methods of their preparation.

Among such methods of preparation is the coagulation of soy protein precipitate employed in the production of tofu from soy milk. Tofu is one of the most important traditional soy foods in the eastern world, with a limited shelf life[4]. Tofu is low in calories, contains a relatively large a mount of iron, and contains little fat[10]. Depending on the coagulant used in manufacturing, the tofu may also be high in calcium and/or magnesium. Coagulation of the protein and oil (emulsion) suspended in the boiled soy milk is the most important step in the production of tofu. This process is accomplished with the aid of coagulants. Coagulation could be achieved by increase in the acidity, extended heating or enzyme activity. Rennet extract from the abomasums of calves has been the traditional coagulant, but it is now substituted with rennet extracted from some bacteria and mould[11]. Acidic coagulation is often achieved by the addition of vinegar or vegetable extracts. This paper aims at investigating the coagulating properties of Sodom apple 
juice, vinegar, lemon juice and rennet as coagulants of soy protein precipitate from soymilk at different temperature.

\section{Materials and Methods}

\section{Plant material}

Soybeans (Glycine max) of yellow variety tax 306-036C were obtained from the International Institute of Tropical Agriculture (IITA), Ibadan, Nigeria. Lemon fruits and leaves of Sodom apple (Calotropis procera) were obtained from Ketu fruit market, Lagos, Nigeria. Rennet and vinegar were obtained from a food grade chemical store and supermarket respectively at Lagos, Nigeria.

\section{Extraction of lemon juice}

The lemon fru its were washed and cut into halves. The juice was extracted using juice extractor after which it was filtered through a sieve to remove the seeds, packed in air tight containers and refrigerated until further analysis.

\section{Extraction of Sodom apple juice}

$45 \mathrm{~g}$ of the leaves of Sodom apple juice was homogenized with $300 \mathrm{ml}$ distilled water and then sieved to remove solid particles. It was centrifuged at $10,000 \mathrm{rpm}$ for 20 minutes in an ultracentrifuge at a temperature of $\leq 2^{\circ} \mathrm{C}$. The supernatant was decanted and stored at $\leq 4^{\circ} \mathrm{C}$ for subsequent analysis.

Production of soy milk

This was carried out to according to the Illinois method as described by Nelson et al.[12].

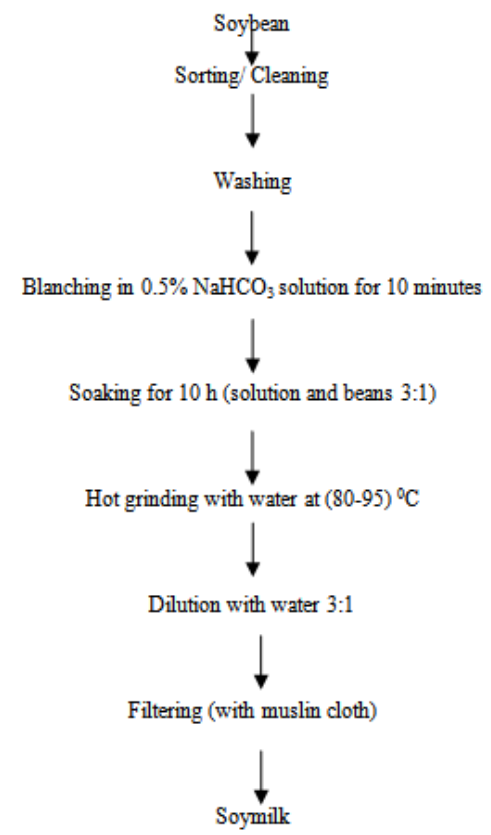

Figure 1. Flow chart of soymilk production

Determination of the physicochemical properties of soymilk

This was carried out according to AOAC methods [13].

Coagulation and precipitation of soy protein with various coagulants

$100 \mathrm{ml}$ of the soymilk sample was heated to different temperature of $50^{\circ} \mathrm{C}, 60^{\circ} \mathrm{C}, 70^{\circ} \mathrm{C}, 80^{\circ} \mathrm{C}, 90^{\circ} \mathrm{C}$ and $100^{\circ} \mathrm{C}$ in separate boiling tubes. $5 \mathrm{ml}$ of each coagulant (Sodo m apple juice, rennet, vinegar, and lemon ju ice) was added separately to each of the boiling tube at different temperatures. The time required for coagulation to take place was noted and recorded. The $\mathrm{pH}$ of each sample and coagulant were noted. The percentage yield for each coagulant at different temperature was calculated as:

$\%$ Yield $=$ we ight of soy protein precipitate $\mathrm{x} 100(\mathrm{w} / \mathrm{v})$

Volume of milk

\section{Statistical Analysis}

Data were reported as mean \pm standard deviation. Statistical analyses were carried out using SPSS for Windows, version 14.0 (SPSS Inc. Chicago, IL.USA).

\section{Results and Discussion}

Precipitation is widely used in downstream processing of biological products, such as proteins[14]. This serves to concentrate and fractionate the target product from various contaminants. This paper reports the coagulating properties of different natural coagulants in soy protein precipitation from soymilk at different temperatures.

\section{Physicochemical properties of soymilk}

The physicochemical properties of soymilk are presented on table 1. A very high content of crude protein was observed. This is far higher than results observed by Salim-ur-Reh man et al.[15] on soymilk and cow milk. The observed high protein content is very encouraging as protein deficiency is a serious cause of ill health and death in developing countries and plays a part in the disease kwashiorkor[16]. Thus, correlating with previous reports on the choice of soybean in combating protein malnutrition[2]. The fat and ash contents were observed to be much higher than those of previous studies $[15,17]$. This may be as result of the method of preparation.

Table 1. Physicochemical composition of soymilk

\begin{tabular}{cc}
\hline Parameters & Results \\
\hline Total solid & $14.0 \pm 0.33$ \\
Totaltitrable acidity & $0.18 \pm 0.03$ \\
Ash & $1.8 \pm 0.25$ \\
Protein content & $23.31 \pm 0.26$ \\
Crude fat & $12.5 \pm 0.40$ \\
\hline
\end{tabular}

Data are mean $\pm \mathrm{SD} ; \mathrm{n}=3$

Effect of different coagulants on soy protein precipitation

Figure 2 shows coagulation time at different temperatures. The coagulation time was observed to decrease with increase in temperature $\left(50-100^{\circ} \mathrm{C}\right) \cdot 100^{\circ} \mathrm{C}$ was the best coagulation time with vinegar having the lowest coagulation time (30 seconds) and rennet having the highest time (4 minutes). However rennet was observed to have a lower coagulation time ( 3 minutes) at $80^{\circ} \mathrm{C}$, which increased thereafter. $80^{\circ} \mathrm{C}$ may thus be said to be the optimum temperature for rennet. Enzy mes are denatured with increasing temperature; therefo re, at temperature above $80^{\circ} \mathrm{C}$ rennet may be inactivated. 
This dependant increase in coagulation time on high temperature corresponds to previous reports by Dybowska and Fujio[18]; and Naz et al.[19].

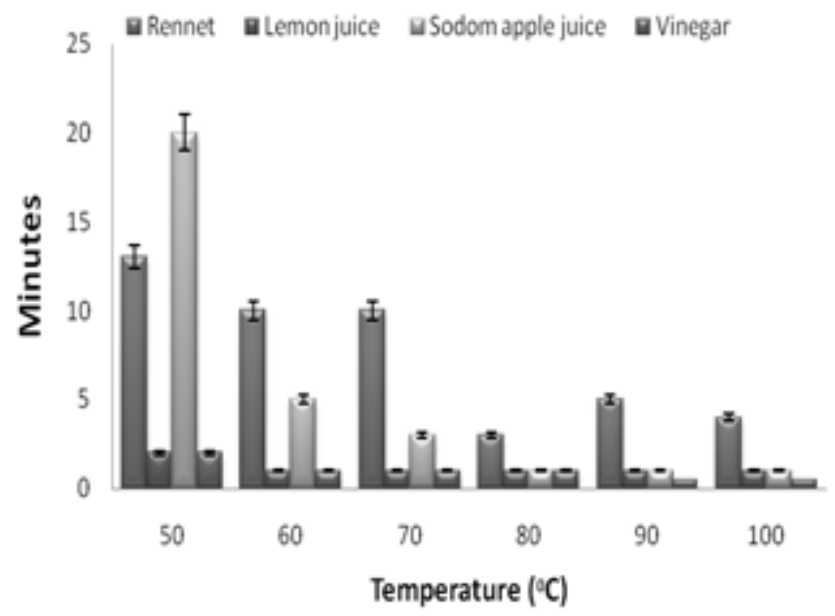

Figure 2. Time of coagulation at different temperature. Values $=$ mean \pm $\mathrm{SD} ; \mathrm{n}=3$

The $\mathrm{pH}$ of coagulant has been reported to greatly affect coagulating efficiency[20]. Furthermore, Naz et al.[19] reported that coagulation is related to the effect of $\mathrm{pH}$ on the enzymatic and aggregation phases of milk coagulation. Figure 3 shows the $\mathrm{pH}$ of soymilk and the coagulants. The $\mathrm{pH}$ of the coagulated proteins by the different coagulants was observed to decrease with increasing temperature $\left(50-100^{\circ} \mathrm{C}\right)$ (figure 4). The optimal $\mathrm{pH}$ was observed at $70^{\circ} \mathrm{C}$ for all coagulants.

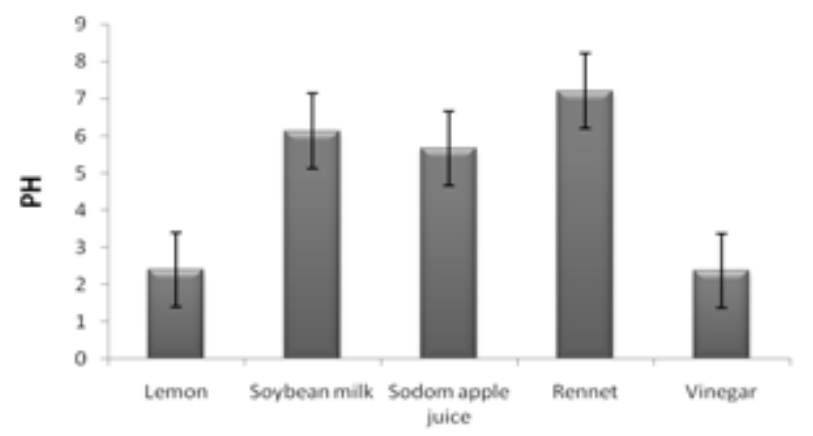

Figure 3. $\mathrm{pH}$ of soybean milk and coagulants. Values $=$ mean $+\mathrm{SD} ; \mathrm{n}=3$

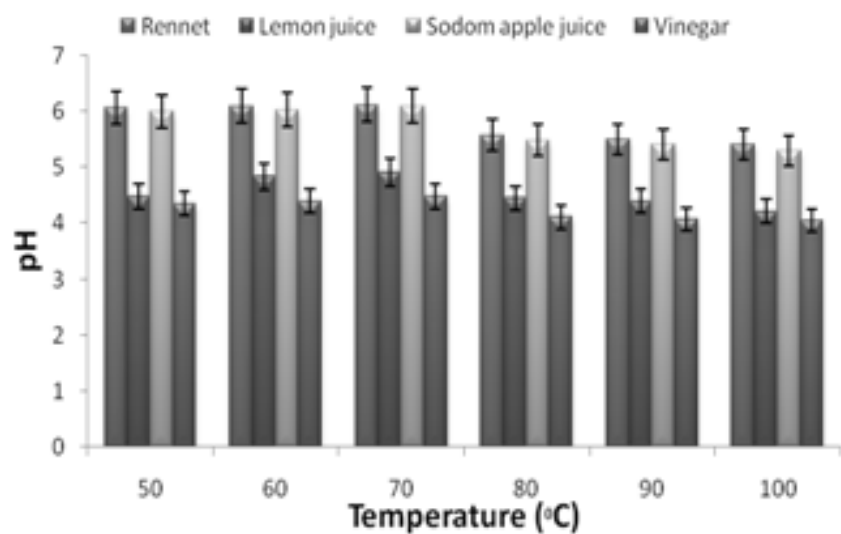

Figure 4. $\mathrm{pH}$ of different samples fortified with coagulants at different temeperatures. Values $=$ mean $\pm \mathrm{SD} ; \mathrm{n}=3$
The effect of coagulation temperature on yield coagulated soy protein precipitate is presented on Figure 5. No significant difference was observed on the effect of coagulating temperatures on the yield of coagulated soy protein precipitate.

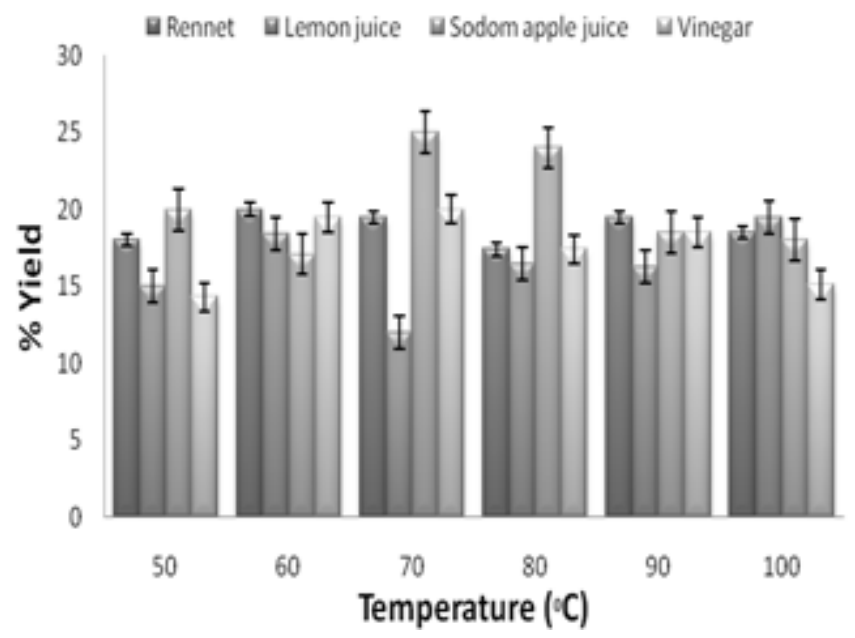

Figure 5. Percentage yield of soy protein precipitate with different coagulants at different temperatures. Values $=$ mean \pm SD; $n=3$

\section{Conclusions}

Results from this study indicate that optimum coagulating activities can be achieved between $70-80^{\circ} \mathrm{C}$. However, the yields by the studied coagulants are not affected by temperature. Thus, implying that temperature modulate the coagulating activities, $\mathrm{pH}$ and not yields of the coagulants. Therefore, production at $70-80^{\circ} \mathrm{C}$ will give the best soy protein quality.

\section{REFERENCES}

[1] Latham, M.C. 1997. Human nutrition in the developing world. Food and Agriculture Organization of the United Nations.

[2] Rweyemamu, L.M.P. 2006. Food-based strategies favouring local multi-nutrient food materials are the best suitable and sustainable strategies for combating micronutrients malnutrition. Moringa and other highly nutritious plant resources: Strategies, standards and markets for a better impact on nutrition in Africa. Accra, Ghana, November 16-18, 2006

[3] Anon. 2012. ASA salutes FP program's soy allocations. http://deltafarmpress.com/asa-salutes-fp-programs-soy-alloc ations. Accessed 1st June, 2012

[4] Zhong, F., Wang, Z., Xu, S., and Shoemaker, C.F., 2007, The evaluation of proteases as coagulants for soy protein dispersions. Food Chem.,100: 1371-1376

[5] FDA, 1999, Food labeling: health claims: soy protein and coronary heart disease. Food and Drug Administration, HHS: final rule: soy protein and coronary heart disease. Fed. Reg., 64:57700-57733. 
[6] Sacks, F.M., Lichtenstein, A., Horn, L.V., Harris, W., Kris-Etherton, P., and Winston, M., 2006, Soy Protein, Isoflavones, and Cardiovascular Health An American Heart Association Science Advisory for Professionals From the Nutrition Committee. Circulation., 113:1034-1044.

[7] NSRL, 2010, Soy Benefits. National Soybean Research Laboratory; http://www.nsrl.uiuc.edu/soy_benefits.html. Accessed 12-9-2010.

[8] Schlick, G., and Bubenheim, D.L., 1993, Quinoa: an emerging "new" crop with potential for CELSS. NASA Technical Paper 3422; Ames Research Center Moffett Field, California 94035-1000.

[9] Derbyshire, E., Wright, D.J., and Boulter, D., 1976, Legumin and vicilin, storage proteins of legume seeds. Phytochem., 15, (1): 3-24.

[10] Van der Riet, W.B., Wight A.W., Cilliers, J.J.L., and Datel, J.M., 1989, Food chemical investigation of tofu and its byproduct okara. Food Chem., 34, (3), 193-202.

[11] Chazarra, S., Sidrach, L., Lopez-Molina, D., and Rodriguez-Lopez, J.N., 2007, Characterization of the milk-clotting properties of extracts from artichoke (Cynara scolymus, L.) flowers. Intl. Dairy J., 17: 1393-1400.

[12] Nelson, A.I., Steinberg, M.P., and Wei, L.S., 1976, Illinois Process for preparation of soymilk. J. Food Sci. 41: 57-61.

[13] AOAC. 1997 Official methods of analy sis of the Association of Analy tical Chemists, 16th Ed., Washington DC.
[14] Zellner, M., Winkler, W., Hayden, H., et al., 2005, Quantitative validation of different protein precipitation methods in proteome analysis of blood platelets. Electrophoresis., 26: 2481-2489

[15] Salim-ur-Rehman, Nawaz, H., Ahmad, M.M., Hussain, S., Murtaza, A., and Shahid, S.H., 2007, Physicochemical and Sensory Evaluation of Ready to Drink Soy-cow Milk Blend. Pak. J. Nutr., 6 (3): 283-285

[16] WHO, FAO, and UNU, 2007, Protein and amino acid requirements in human nutrition. WHO Press.

[17] Iwuoha, C.I., and Umunnakwe, K.E. (1997). Chemical, physical and sensory characteristics of soymilk as affected by processing method, temperature and duration of storage. Food Chem., 59 (3): 313-379.

[18] Dybowska, E., and Fujio, Y., 1996. Effect of temperature and glucono-o-lactone GDL concentration on milk aggregation and gelation process as revealed by optical method. Milchwissenschaft., 51: 557-560.

[19] Naz, S., Masud, T., and Nawaz, M.A., 2009, Characterization of milk coagulating properties from the extract of Withania coagulans. Intl. J. Dairy Tech., 62, (3): 315-320.

[20] Lim, B.T., De Man, J.M., De Man, L., and Buzzell, R.I., 1990, Yield and quality of tofu as affected by soybean and soymilk characteristics calcium sulphate coagulant. J. Food Sci., 55: 1088-1092. 